\title{
Inhibitory effect of bacteriocin-producing lactic acid bacteria against histamine-forming bacteria isolated from Myeolchi-jeot
}

\author{
Eun-Seo Lim
}

\begin{abstract}
The objectives of this study were to identify the histamine-forming bacteria and bacteriocin- producing lactic acid bacteria (LAB) isolated from Myeolchi-jeot according to sequence analysis of the 165 rRNA gene, to evaluate the inhibitory effects of the bacteriocin on the growth and histamine accumulation of histamine-forming bacteria, and to assess the physico-chemical properties of the bacteriocin. Based on 16S rRNA gene sequences, histamine-forming bacteria were identified as Bacillus licheniformis MCH01, Serratia marcescens MCH02, Staphylococcus xylosus MCH03, Aeromonas hydrophila MCH04, and Morganella morganii MCH05. The five LAB strains identified as Pediococcus acidilactici MCL11, Leuconostoc mesenteroides MCL12, Enterococcus faecium MCL13, Lactobacillus sakei MCL14, and Lactobacillus acidophilus MCL15 were found to produce an antibacterial compound with inhibitory activity against the tested histamine-producing bacteria. The inhibitory activity of these bacteriocins obtained from the five LAB remained stable after incubation at $\mathrm{pH} 4.0-8.0$ and heating for $10 \mathrm{~min}$ at $80^{\circ} \mathrm{C}$; however, the bacteriocin activity was destroyed after treatment with papain, pepsin, proteinase K, a-chymotrypsin, or trypsin. Meanwhile, these bacteriocins produced by the tested LAB strains also exhibited histamine-degradation ability. Therefore, these antimicrobial substances may play a role in inhibiting histamine formation in the fermented fish products and preventing seafood-related food-borne disease caused by bacterially generated histamine.
\end{abstract}

Keywords: Bacteriocin, Histamine, Lactic acid bacteria

\section{Background}

Myeolchi-jeot, a traditional Korean salted and fermented seafood, is made of anchovies (Engraulis japonicas) and is mostly used as an ingredient in Kimchi. Since proteins are broken down into precursor amino acids of biogenic amines through the action of digestive enzymes and microbes during the fermentation process, it contains relatively high concentrations of biogenic amines (Mah et al., 2002). According to their chemical structure, biogenic amines are classified into aliphatic (putrescine, cadaverine, spermine, spermidine), aromatic (tyramine, phenlethylamine), and heterocyclic (histamine, tryptamine) (Santos, 1996). High doses of biogenic amines such as histamine $(>500 \mathrm{mg} / \mathrm{kg})$ and tyramine $(100-800 \mathrm{mg} / \mathrm{kg})$ contained mainly in fermented

Correspondence: limsm020@tu.ac.kr

Department of Food Science and Nutrition, Tongmyong University, Busan

608-735, Republic of Korea

(c) The Author(s). 2016 Open Access This article is distributed under the terms of the Creative Commons Attribution 4.0 International License (http://creativecommons.org/licenses/by/4.0/), which permits unrestricted use, distribution, and reproduction in any medium, provided you give appropriate credit to the original author(s) and the source, provide a link to the Creative Commons license, and indicate if changes were made. The Creative Commons Public Domain Dedication waiver (http://creativecommons.org/publicdomain/zero/1.0/) applies to the data made available in this article, unless otherwise stated. foods can cause adverse health effects to consumers (Joosten and Nuńez, 1996).

Histamine is the causative agent of scombroid poisoning which is often manifested by a wide variety of symptoms such as rash, urticarial, nausea, vomiting, diarrhea, abdominal cramp, hypotension, localized inflammation, headache, palpitation, and severe respiratory distress (Taylor, 1986). Histamine is a basic nitrogenous compound formed mainly through the decarboxylation of histidine by exogenous decarboxylases released from the many different bacterial species associated with salted and fermented seafoods including Myeolchi-jeot (An and Ben-Gigirey, 1998). In Myeolchi-jeot, Bacillus licheniformis has been known to raise levels of histamine in retail canned anchovies during the storage at an ambient temperature Mah and Hwang (2003). The presence of histidine decarboxylase activity has been described in different microbial groups such as seafood-borne bacteria, 
spoilage microorganisms, and lactic acid bacteria (López-Sabater et al., 1994).

Fortunately, in recent years, some lactic acid bacteria (LAB) have been reported to degrade biogenic amine through the production of amine oxidase enzymes or antimicrobial substances (Garciz-Ruiz et al., 2011; Joosten and Nuńez, 1996). LAB that are usually designated as generally recognized as safe (GRAS) status in foods can also exert a biopreservative effect against other microorganisms as a result of competition for nutrients and/or of the production of antagonistic compounds such as organic acids, diacetyl, acetoin, hydrogen peroxide, antibiotics, and bacteriocins (Schillinger et al., 1996). Among anti-microbial metabolites, bacteriocins are ribosomally synthesized and defined as extracelluarly released peptides or protein molecules produced by specific bacteria during the primary phase of growth, though antibiotics are usually secondary metabolites (Zacharof and Lovitt, 2012). Brillet et al. (2005) has shown that bacteriocin produced by Carnobacterium divergens $\mathrm{V} 41$ can be used as a biopreservative to inhibit the growth Listeria monocytogenes in cold smoked salmon; therefore, bacteriocins can be applied in the seafood industry for extension of shelf life as natural preservatives against pathogens and food spoilage.

In particular, outgrowth of histamine producer Lactobacillus buchneri St2A was almost completely inhibited by treatment of bacteriocin-producing enterococci and Lactococcus lactis strain as fermentation starters (Joosten and Nuńez, 1996). Tabanelli et al. (2014) reported that bacteriocin forming lactococci strains were able to reduce the growth extent and histamine accumulation of Streptococcus thermophilus PRI60. The studies reported previously indicate that the applications of bacteriocins in food industries can extend shelf life of foods, inhibit growth of foodborne pathogens during the manufacture of food, prevent formation of toxic substances by harmful bacteria, ameliorate the economic losses due to food spoilage, and reduce the application of chemical preservatives (Gálvez et al., 2007).

The objectives of this study were to (1) identify the histamine-forming bacteria and bacteriocin-producing LAB isolated from Myeolchi-jeot according to sequence analysis of the $16 \mathrm{~S}$ rRNA gene, (2) evaluate the inhibitory effects of the bacteriocin on the growth and histamine accumulation of histamine-forming bacteria, and (3) assess the physico-chemical properties of the bacteriocin.

\section{Methods}

\section{Isolation and identification of histamine-forming bacteria} and $L A B$

Five samples of salted-fermented anchovy were obtained from retail stores in Busan and aseptically collected for these experiments. Each sample (50 g) was diluted with sterile peptone water $(450 \mathrm{~mL})$ and homogenized at high speed for $2 \mathrm{~min}$ in stomacher. The decimal serial dilutions of the homogenates were then subsequently prepared using a sterile peptone water, and $1.0-\mathrm{mL}$ aliquots of the dilutes were inoculated into brain heart infusion (BHI) agar (BD Difco Co., Sparks, MD, USA) and incubated for $48 \mathrm{~h}$ at $37{ }^{\circ} \mathrm{C}$. To isolate histamine-forming bacteria, each strain collected from the plates was subcultured for $48 \mathrm{~h}$ at $35{ }^{\circ} \mathrm{C}$ in decarboxylating broth contained L-histidine monohydrochloride monohydrate (Sigma-Aldrich, St Louis, MO, USA, $1 \mathrm{~g} / \mathrm{L}$ ) and pyridoxal-5' -phosphate (Sigma-Aldrich, $1 \mathrm{mg} / \mathrm{L}$ ) according to the method of Bover-Cid and Holzapfel (1999) with minor modifications. The cell culture $(0.1 \mathrm{~mL})$ was spread on trypticase soy agar (TSA, BD Difco Co.) supplemented with $2.0 \%(w / v)$ L-histidine hydrochloride monohydrate. After incubation under anaerobic conditions for 4 days at $35{ }^{\circ} \mathrm{C}$ (Anoxomat system, MART Co., Netherland), the colonies with blue or purple color on the plates were considered as histamine-forming bacteria. Meanwhile, to distinguish lactic acid-producing bacteria from salted-fermented anchovy, the homogenized sample was spread directly onto the surface of MRS (BD Difco Co.) agar plates containing $1 \% \mathrm{CaCO}_{3}$. After incubation under aerobic conditions for $48 \mathrm{~h}$ at $37^{\circ} \mathrm{C}$, the colonies surrounded by a clear zone were randomly selected from the plates, purified on MRS agar, and examined histamine production as the abovementioned. The identity of histamine-forming isolates was confirmed by using 16S rRNA gene sequence analysis (Chen et al., 2008). Amplification of the isolates was performed with the universal primers UNI-L (5'-AGAGTTT GATCATGGCTCAG-3') and UNI-R (5'-GTGTGACGG GCGGTGTGTAC-3'). Bacterial cells were cultivated in $\mathrm{BHI}$ broth at $37^{\circ} \mathrm{C}$ with shaking overnight and centrifuged at $7000 \times g$ for $10 \mathrm{~min}$. After washing, the cell pellets were resuspended in PBS (pH 7.0) and lysed by $20 \%$ sodium dodecyl sulfate (SDS). After the boiling process for $20 \mathrm{~min}$ at $85{ }^{\circ} \mathrm{C}$, the cell debris was removed by centrifugation $\left(13,000 \times g, 5 \mathrm{~min}, 4^{\circ} \mathrm{C}\right)$. DNA in the supernatant was precipitated by addition of 70\% ethanol and used as template DNA for polymerase chain reaction (PCR). PCR amplification was carried out with a reaction mixture consisting of $10 \mathrm{mM}$ Tris- $\mathrm{HCl}$ (pH 8.3), $50 \mathrm{mM} \mathrm{KCl}, 1.5 \mathrm{mM} \mathrm{MgCl}_{2}$, 20 pmol of each primer, $0.2 \mathrm{mM}$ deoxynucleotide triphosphates, 0.5 U of Taq DNA polymerase (Applied Biosystem, Foster City, CA, USA), and template DNA (10 ng). Cycle conditions were an initial denaturation for $4 \mathrm{~min}$ at $94{ }^{\circ} \mathrm{C}$, followed by 35 cycles of $30 \mathrm{~s}$ denaturation at $94{ }^{\circ} \mathrm{C}, 30 \mathrm{~s}$ annealing at $55{ }^{\circ} \mathrm{C}, 1 \mathrm{~min}$ primer extension at $72{ }^{\circ} \mathrm{C}$, followed by a final extension for $7 \mathrm{~min}$ at $72{ }^{\circ} \mathrm{C}$ in a PCR Thermal Cycler (Bio-Rad Laboratories Ltd., Canada). To identify the LAB isolates which do not produce histamine, 
the universal primer used for identification of LAB was 27F (5' -AGAGTTTGATCCTGGCTCAG-3') and 1492RF (5'-GGTTACCTTGTTACGACTT-3'). Thermocycling was carried out using denaturation step at $94{ }^{\circ} \mathrm{C}$ for $1 \mathrm{~min}$, annealing at $55{ }^{\circ} \mathrm{C}$ for $1 \mathrm{~min}$, and extension at $72{ }^{\circ} \mathrm{C}$ for $2 \mathrm{~min}$, for a total of 30 cycles. Amplicons were visualized on a $1.5 \%$ agarose gel staining with ethidium bromide to confirm successful amplification and then PCR product was purified using a QIAquick PCR Purification Kit (Qiagen, Valencia, CA, USA). The amplified DNA was directly sequenced with a DNA sequencer (ABI Prism ${ }^{\odot} 3730$ Avant Genetic Analyzer, Applied Biosystem) and sequence similarity searching was performed using the National Center for Biotechnology Information (NCBI) Basic Local Align Search Tool (BLAST).

\section{Preparation of bacteriocin solution and determination of bacteriocin activity}

To prepare the bacteriocin solution of the LAB strains, the culture extracts of the isolated $\mathrm{LAB}$ were obtained after 24-h incubation at $37{ }^{\circ} \mathrm{C}$ in MRS broth. The cultures were centrifuged at $7000 \times g$ for $10 \mathrm{~min}$ at $4{ }^{\circ} \mathrm{C}$. The cell-free supernatant (CFS) was then adjusted with $1 \mathrm{~N}$ of $\mathrm{NaOH}$ to $\mathrm{pH} 6.5$ to avoid effect of acid, treated with catalase $(200 \mathrm{U} / \mathrm{mL})$ for $30 \mathrm{~min}$ at $25{ }^{\circ} \mathrm{C}$ to remove hydrogen peroxide, and filtered through a $0.22-\mu \mathrm{m}$ membrane filter (Millipore Corp., USA). Crude bacteriocin was precipitated from the CFS by $50 \%(w / v)$ ammonium sulfate and the precipitates were kept overnight at $4{ }^{\circ} \mathrm{C}$ with gentle stirring. After centrifugation (at $12,000 \times g$ for $30 \mathrm{~min}$ at $4{ }^{\circ} \mathrm{C}$ ), the resulting pellets were dissolved in $20 \mathrm{mM}$ sodium phosphate buffer $(\mathrm{pH}$ 6.5) and dialyzed overnight at $4{ }^{\circ} \mathrm{C}$ against distilled water using dialysis membrane (molecular weight cutoff, 1,000; Spectrum Labs., Gardena, CA, USA). The antimicrobial activity of the bacteriocin was assayed by microtiter plate assay (Holo et al., 1991), using histamine-forming bacteria as an indicator strain. In brief, each well of the microtiter plate (BD Falcon, Franklin Lakes, NJ, USA) was filled with $800 \mu \mathrm{L}$ of BHI broth, $100 \mu \mathrm{L}$ of a twofold serial dilution of the crude bacteriocin solution or PBS ( $\mathrm{pH} 7.0)$, and $100 \mu \mathrm{L}$ of cell cultures $\left(1.0 \times 10^{5} \mathrm{CFU} / \mathrm{mL}\right)$ of indicator organism grown in BHI broth. The plates were then placed in an aerobic incubator for $12 \mathrm{~h}$ at $37{ }^{\circ} \mathrm{C}$. The extent of growth inhibition was measured spectrophotometrically at $600 \mathrm{~nm}$ using microplate reader (Bioteck, Inc., Korea). One bacteriocin unit $(\mathrm{BU} / \mathrm{mL})$ was arbitrarily defined as the reciprocal of the highest dilution inhibiting the $50 \%$ growth of the indicator strain compared to the control.
Inhibitory effect of the bacteriocin on histamine accumulation Histamine-forming bacteria isolated from the samples were seeded in TSB enriches with L-histidine hydrochloride monohydrate $(0.5 \%)$ and pyridoxal- $\mathrm{HCl}(0.0005 \%)$ and incubated at $35{ }^{\circ} \mathrm{C}$ for $24 \mathrm{~h}$. The cultures $(1 \mathrm{~mL})$ were transferred to test tubes containing the same broth $(9 \mathrm{~mL})$ and bacteriocin solution (100 and $200 \mathrm{BU} / \mathrm{mL}$ ) from the $\mathrm{LAB}$ isolates and incubated for $24 \mathrm{~h}$ at $35^{\circ} \mathrm{C}$. These broth cultures were centrifuged $\left(7000 \times g, 10 \mathrm{~min}, 4{ }^{\circ} \mathrm{C}\right)$ and filtered through a $0.22-\mu \mathrm{m}$ membrane filter. The histamine content in the cultures was performed according to the procedure modified by Eerola et al. (1993) and Mah and Hwang (2003) using high-pressure liquid chromatography (HPLC, Hitachi, Tokyo, Japan). Briefly, $1 \mathrm{~mL}$ of the cell cultures or standard histamine solutions was added to $9 \mathrm{~mL}$ of 0.4 M perchloric acid (Merck, Darmstadt, Germany) and vigorously mixed. The mixture was then centrifuged at $3000 \times g$ for $10 \mathrm{~min}$ and the supernatant was filtered through Whatman paper No. 1 . The samples $(1 \mathrm{~mL})$ were mixed with $2 \mathrm{M}$ sodium hydroxide $(200 \mu \mathrm{L})$ and saturated sodium bicarbonate solution $(300 \mu \mathrm{L})$. Subsequently, the samples were added with $2 \mathrm{~mL}$ of $10 \mathrm{mg} / \mathrm{mL}$ dansyl chloride (Sigma-Aldrich) solution prepared in acetone and the mixture solution was incubated at $40{ }^{\circ} \mathrm{C}$ for $45 \mathrm{~min}$. Residual dansyl chloride was removed by addition of $25 \%$ ammonium hydroxide $(100 \mu \mathrm{L})$. After incubation for $30 \mathrm{~min}$ at room temperature, the volume of mixture was adjusted to $5 \mathrm{~mL}$ with acetonitrile. Finally, the dansyl derivatives were centrifuged at $2500 \times g$ for $5 \mathrm{~min}$, and the supernatant was filtered through a $0.22-\mu \mathrm{m}$ filter. A Nova-Pak $\mathrm{C}_{18}$ column $(150 \mathrm{~mm} \times 3.9 \mathrm{~mm}$, Waters, Milford, MA, USA) was used for the separation of histamine, and acetonitrile (solvent $\mathrm{B}$ ) as the mobile phases at the flow rate of $1 \mathrm{~mL} / \mathrm{min}$. The sample volume injected was $20 \mu \mathrm{L}$, and the eluted sample was monitored at $254 \mathrm{~nm}$. All experiments were performed in triplicate. Data are expressed as means \pm standard deviation (SD) and analyzed with SPSS program (ver. 12.0, SPSS Inc., Chicago, IL, USA). Then data comparisons were performed with paired $t$ test and differences were considered statistically significant when $P$ values were $<0.05$.

\section{Physical and chemical properties of the bacteriocn}

The effect of $\mathrm{pH}$ on antimicrobial activity of the crude bacteriocin was determined by incubating the crude bacteriocin in various buffers $[0.1 \mathrm{M}$ acetate buffer (pH 2.0-5.0), 0.1 M phosphate buffer ( $\mathrm{pH}$ 6.0-7.0), and Tris $\mathrm{HCl}(\mathrm{pH} 8.0-10.0)]$ with $\mathrm{pH}$ ranging from 2 to 10 for $24 \mathrm{~h}$ at $37{ }^{\circ} \mathrm{C}$. To evaluate the heat stability, the crude bacteriocin was heated for $10 \mathrm{~min}$ at 80,100 , and $120{ }^{\circ} \mathrm{C}$. Sensitivity of the crude bacteriocin to proteolytic enzymes was examined by incubation of the sample for $1 \mathrm{~h}$ at $37^{\circ} \mathrm{C}$ after treatment with the following enzymes $(1 \mathrm{mg} / \mathrm{mL})$ : proteinase $\mathrm{K}$ in $50 \mathrm{mM}$ Tris- $\mathrm{HCl}(\mathrm{pH} 7.5)$, trypsin in $50 \mathrm{mM}$ Tris- $\mathrm{HCl}(\mathrm{pH} 8.0)$, pepsin in $100 \mathrm{mM}$ 
Trish- $\mathrm{HCl}(\mathrm{pH} 3.0)$, papain in 50 sodium phosphate acetate ( $\mathrm{pH} 5.0$ ), and $\alpha$-chymotrypsin in $20 \mathrm{mM}$ Tris$\mathrm{HCl}(\mathrm{pH}$ 8.0). Following incubation, the enzymes were heat inactivated for $3 \mathrm{~min}$ at $100{ }^{\circ} \mathrm{C}$. The residual bacteriocin activity was determined by the microtiter plate assay as described earlier. In addition, the bacteriocin treated under each physical or chemical condition were added to TSB containing L-histidine hydrochloride monohydrate $(0.5 \%)$ and pyridoxal- $\mathrm{HCl}(0.0005 \%)$ and inoculated with initial population of approximately $1.0 \times 10^{5} \mathrm{CFU} / \mathrm{mL}$ of histamine-forming bacteria. After incubation for $24 \mathrm{~h}$ at $35^{\circ} \mathrm{C}$, histamine levels in the cultures were analyzed using HPLC described above. All the experiments were done in triplicate.

\section{Results and discussion}

Isolation and identification of histamine-forming bacteria and bacteriocin-producing LAB

The results of the identification of histamine-forming bacteria and bacteriocin-producing $\mathrm{LAB}$ found in Myeolchi-jeot are presented in Table 1. Based on $16 \mathrm{~S}$ rRNA gene sequences, histamine-forming bacteria were identified as B. licheniformis MCH01, Serratia marcescens MCH02, Staphylococcus xylosus MCH03, Aeromonas hydrophila MCH04, and Morganella morganii $\mathrm{MCH} 05$, with $98.0-99.9 \%$ similarity to the GenBank database. Meanwhile, 53 LAB strains isolated from Myeolchi-jeot were screened for the inhibition activity against histamine-forming bacteria, using a microtiter plate assay. Out of these strains, five strains (9.4\%) presented $98.3-100.0 \%$ similarity with the 16S rRNA sequences reported for Pediococcus acidilactici MCL11, Leuconostoc mesenteroides MCL12, Enterococcus faecium MCL13, Lactobacillus sakei MCL14, and Lactobacillus acidophilus MCL15 in the GenBank database.

Several fish species including tuna, mackerel, sardines, and anchovy contain high levels of free histidine in their tissues. These fishes subjected to temperature abuse after the catch and before consumption can cause formation of histamine from histidine by bacterial histidine decarboylases (Visciano et al., 2012). Histamine-rich foods may cause food intolerance in sensitive individuals and histamine poisoning that is a common seafoodborne disease causing various symptoms such as rash, nausea, vomiting, fever, diarrhea, headache, itching, flushing, and abdominal cramps (Taylor, 1986). Proteus vulgaris, Proteus mirabilis, Clostridium perfringens, Enterobacter aerogenes, Klebsiella pneumonia, Hafnia alvei, and Vibrio alginolyticus and enterobacteriaceae have been isolated from fish and described as the predominant histamine-forming bacteria (Shalaby, 1996; Kung et al., 2009). Moreover, there have been several reports describing amino acid decarboxylation activity of different genera, such as Acinetobacter, Aeromonas, Bacillus, Cedecea, Citrobacter, Clostridium, Escherichia, Klebsiella, Plesiomonas, Proteus, Pseudomonas, Salmonella, Serratia, Shigella, and Vibrio, and of some lactic acid bacteria (Kim et al., 2009). Our data are partially consistent with results reported by Guan et al. (2011) and Kung et al. (2009). The commonly isolated genera from Myeolchi-jeot were Microbacterium sp., Kocuria sp., Vibrio sp., Psychrobacter sp., Halomonas sp., Brevibacillus sp., Bacillus sp., Enterococcus sp., Tetragenococcus sp., Weissella sp., Lactobacillus sp., and Staphylococcus sp. (Guan et al., 2011). Among bacterial communities in Jeotgal, M. morganii, K. pneumoniae, and $H$. alvei have been known as the strains causing scombroid poisoning (often called "histamine poisoning") (Kung et al., 2009). In addition, Staphylococcus epidermidis obtained during the ripening of anchovies showed a powerful histamine-forming activity (Hernández-Herrero et al. 1999).

\section{Bacteriocin activity of the isolates against histamine- forming bacteria}

As shown in Table 2, the five LAB strains isolated from Myeolchi-jeot were found to produce an antibacterial compound with inhibitory activity against histamineproducing bacteria such as $B$. licheniformis MCH01, $S$. marcescens $\mathrm{MCH} 02$, S. xylosus $\mathrm{MCH} 03$, A. hydrophila $\mathrm{MCH} 04$, or $M$. moarganii MCH05. The crude bacteriocin of $P$. acidilactici MCL11 inhibited the growth of $B$.

Table 1 Identification of histamine-forming bacteria and lactic acid bacteria isolated from Myeolchi-jeot using 16S rRNA gene sequence analysis

\begin{tabular}{|c|c|c|c|c|c|c|c|}
\hline \multicolumn{4}{|c|}{ Histamine-forming bacteria } & \multicolumn{4}{|l|}{$\angle A B$} \\
\hline Strain & $\begin{array}{l}\text { Accession no. } \\
\text { related strain } \\
\text { in } \mathrm{NCB}\end{array}$ & Similarity (\%) & Identification & Strain & $\begin{array}{l}\text { Accession no. } \\
\text { related strain } \\
\text { in NCBI }\end{array}$ & Similarity (\%) & Identification \\
\hline $\mathrm{MCH} 01$ & EF433410 & 98.6 & Bacillus licheniformis & MCL11 & EF059986 & 99.9 & Pediococcus acidilactici \\
\hline $\mathrm{MCH} 02$ & EF194094 & 99.7 & Serratia marcescens & MCL12 & KF673541 & 100.0 & Leuconostoc mesenteroides \\
\hline $\mathrm{MCHO3}$ & EU266748 & 99.9 & Staphylococcus xylosus & MCL13 & EU887814 & 99.2 & Enterococcus faecium \\
\hline $\mathrm{MCHO} 4$ & AY538658 & 99.0 & Aeromonas hydrophila & MCL14 & AB650590 & 98.3 & Lactobacillus sakei \\
\hline MCH05 & AB680150 & 98.0 & Morganella morganii & MCL15 & KT222158 & 99.5 & Lactobacillus acidophilus \\
\hline
\end{tabular}


Table 2 Antibacterial activity of the bacteriocin produced by lactic acid bacteria against histamine-forming bacteria isolated from Myeolchi-jeot

\begin{tabular}{|c|c|c|c|c|c|}
\hline \multirow[t]{3}{*}{ Indicator organism } & \multicolumn{5}{|c|}{ Bacteriocin activity (BU/mL) } \\
\hline & \multicolumn{5}{|l|}{$L A B$} \\
\hline & $\begin{array}{l}\text { Pediococcus } \\
\text { acidilactici MCL11 }\end{array}$ & $\begin{array}{l}\text { Leuconostoc } \\
\text { mesenteroides MCL12 }\end{array}$ & $\begin{array}{l}\text { Enterococcus } \\
\text { faecium MCL13 }\end{array}$ & $\begin{array}{l}\text { Lactobacillus } \\
\text { sakei MCL14 }\end{array}$ & $\begin{array}{l}\text { Lactobacillus } \\
\text { acidophilus MCL15 }\end{array}$ \\
\hline Bacillus licheniformis MCHO1 & 256 & ND & ND & ND & ND \\
\hline Serratia marcescens MCHO2 & ND & 128 & ND & 256 & ND \\
\hline Staphylococcus xylosus MCHO3 & 512 & ND & 64 & ND & ND \\
\hline Aeromonas hydrophila MCHO4 & ND & ND & 256 & ND & 64 \\
\hline Morganella morganii MCH05 & ND & ND & ND & 128 & ND \\
\hline
\end{tabular}

ND not detected

licheniformis MCH01 and S. xylosus MCH03. In particular, P. acidilactici MCL11 showed the strongest antimicrobial activity $(512 \mathrm{BU} / \mathrm{mL})$ against $S$. xylosus MCH03. The antimicrobial compound produced by $L$. mesenteroides MCL12 (128 BU/mL) and L. sakei MCL14 $(256 \mathrm{BU} / \mathrm{mL})$ strains showed activity against $S$. marcescens $\mathrm{MCH} 02$. The crude bacteriocin produced by $E$. faecium MCL13 showed an antimicrobial activity of 64 and $256 \mathrm{BU} / \mathrm{mL}$ against S. xylosus MCH03 and A. hydrophila MCH04, respectively. L. acidophilus MCL15 was also found to have a bacteriocin activity against $A$. hydrophila $\mathrm{MCH} 04$, which was weaker than that of $E$. faecium MCL13.

Joosten and Nunez (1996) reported that the bacteriocinproducing enterococci and $L$. lactis strains completely inhibited the outgrowth of histamine producer L. buchneri St2A; therefore, no histamine formation was detected in the cheeses made with bacteriocin-producing starters. Our results are in agreement with the findings of previous studies. Gómez-Sala et al. (2015) demonstrated that analysis of 1245 LAB isolates obtained from fish, seafood, and fish products showed that 197 exerted direct antimicrobial activity against 20 spoilage and food-borne pathogenic microorganisms. Furthermore, LAB isolates selected on the basis of their direct antimicrobial activity were identified as E. faecium, E. faecalis, Pediococcus pentosaceus, Weissella cibaria, L. sakei subsp. carnosus, L. sakei subsp. sakei, Lactobacillus curvatus, and L. mesenteroides subsp. cremoris based on $16 \mathrm{~S}$ rDNA sequences. L. mesenteroides HK4, HK5, and HK11 and Streptococcus salivarius HK8 strains isolated from Jeotgal were also chosen by preliminary bacteriocin activity test (Cho and Do, 2006). L. lactis subsp. lactis VR84 produced nisin Z induced the death of the histamine producing strain $S$. thermophilus PRI60. However, L. lactis subsp. lactis EG46-produced lacticin 481 did not show a lethal action against PRI60 strain, but were able to reduce its growth extent and histamine accumulation (Tabanelli et al., 2014). Furthermore, the bacteriocin produced by $L$. case $i$ was able to inhibit the activity of the histamine-forming bacteria such as Pseudomonas sp.,
Proteus morganii, and Micrococcus sp. (Nugrahani et al., 2016). S. xylosus no. 0538 obtained from a salted and fermented anchovy (Myeolchi-jeot) possessed not only the greater capability to degrade histamine but a detectable ability to degrade tyramine as well. In addition, this strain was also found to produce the bacteriocin-like inhibitory substance(s) and have the highest antimicrobial activity against $B$. licheniformis strains defined as amine producers. S. xylosus no. 0538 exhibited significantly greater ability to degrade histamine, degrading histamine to about $62-68 \%$ of its initial concentration within $24 \mathrm{~h}$ (Mah and Hwang, 2009).

\section{Reduction of histamine accumulation by the bacteriocin of $L A B$}

As shown in Table 3, the five histamine-producing bacteria isolated from Myeolchi-jeot had strong ability to produce histamine. Among the tested strains, the highest level of histamine $(2869.4 \pm 49.0 \mathrm{mg} / \mathrm{L})$ formation was observed for the M. morganii MCH05 strain. In addition, the concentration of histamine produced by $S$. xylosus MCH03 $(2257 \pm 30.7 \mathrm{mg} / \mathrm{L})$ strain was higher than that produced by $B$. licheniformis MCH01 (1699.3 $\pm 35.6 \mathrm{mg} / \mathrm{L})$, S. marcescens $\mathrm{MCH} 02(1987.2 \pm 27.8 \mathrm{mg} / \mathrm{L})$, and $A$. hydrophila MCH04 $(1655.5 \pm 41.2 \mathrm{mg} / \mathrm{L})$. Meanwhile, the treatment with 100 and $200 \mathrm{BU} / \mathrm{mL}$ of the bacteriocin obtained from the tested LAB significantly reduced the histamine content of the five histamine-producing bacteria. After $24 \mathrm{~h}$ of incubation in the presence of the bacteriocin (200 BU/ $\mathrm{mL}$ ) of $P$. acidilactici MCL11, histamine contents of $B$. licheniformis MCL01 and S. xylosus MCH03 were reduced by 49 and $27 \%$, respectively, as compared to the control (without bacteriocin). The histamine accumulation of $S$. xylosus $\mathrm{MCHO} 3$ and A. hydrophilia $\mathrm{MCHO} 4$ at $24 \mathrm{~h}$ of incubation in the presence of the bacteriocin of E. faecium MCL13 was significantly inhibited compared with the control group. The bacteriocin obtained from L. sakei MCL14 was effective in degrading histamine produced by $S$. marcescens $\mathrm{MCH} 02$ and $\mathrm{M}$. morganii $\mathrm{MCH} 05$ strains. These bacteriocins produced by L. mesenteroides MCL12 


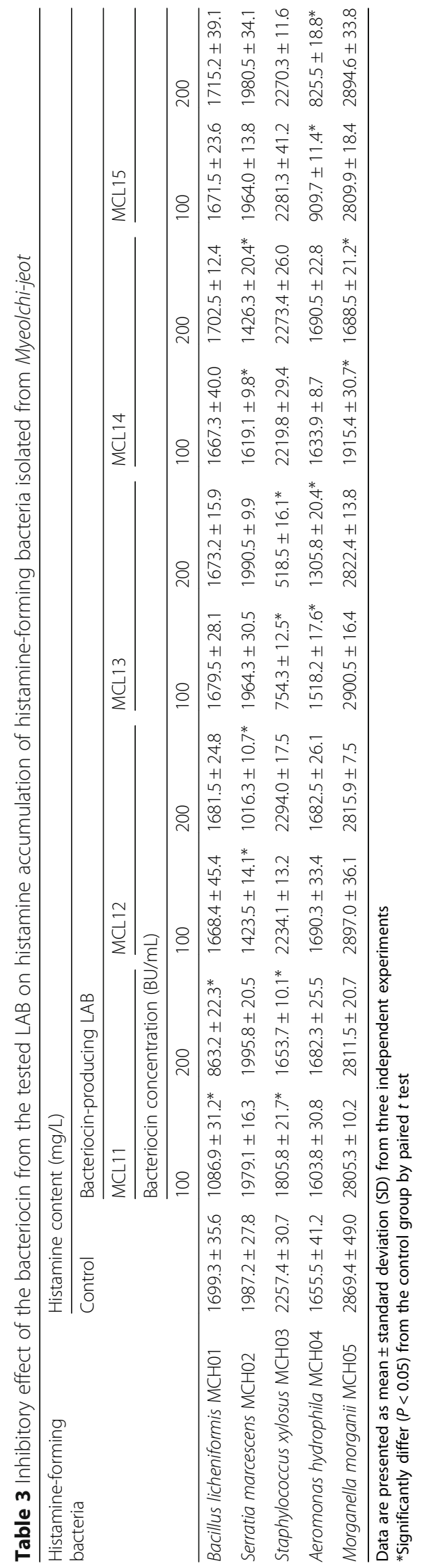


and $L$. acidophilus MCL15 strains also exhibited excellent histamine degradation ability. The histamine degradation ability of these bacteriocins increased in a concentrationdependent manner. The reduction of histamine content by treatment with these bacteriocins may be related to antagonistic activity of these antibacterial substances against histamine-producing bacteria.

Prolific histamine formers in Indian anchovy were identified as $M$. morganii, P. vulgaris, and E. aerogenes, and produced high histamine content of 104.1-203.0 mg/ $100 \mathrm{~mL}$ (Rodtong et al., 2005). Kim et al. (2009) noted that the histamine contents in fish, squid, and shellfish samples remarkably increased up to $36.6-2123.9 \mathrm{mg} / \mathrm{kg}$ after $24 \mathrm{~h}$ of storage at $25^{\circ} \mathrm{C}$, while the contents began to gradually increase after $2-3$ days of storage at $4-10{ }^{\circ} \mathrm{C}$. The dominant microbial group in these samples was enterobacteria throughout the storage period. In our results, the histamine-producing isolates from Myeolchi-jeot were identified as B. licheniformis, S. marcescens, S. xylosus, A. hydrophila, and $M$. morganii and these strains were capable of producing histamine in the range of 1655.5 to $2869.4 \mathrm{mg} / \mathrm{L}$. Consequently, in raw fish, histamine content is linked to the type of histamine-forming bacteria, the type of seafood, and temperature/time storage conditions (Visciano et al., 2012).

Regarding to the inhibition of histamine formation, Zaman et al. (2011) observed that Staphylococcus carnosus FS19 and Bacillus amyloiquefaciens FS05 isolated from fish sauce which possess amine oxidase activity were found to be effective in reducing biogenic amine accumulation, and histamine concentration was reduced by 27.7 and $15.4 \%$ by FS19 and FS05, respectively, which is in disagreement with our observations that the LAB isolates tested in our study showed histamine degradation capacity by production of the antimicrobial substance such as bacteriocin. The histamine levels produced by $B$. licheniformis MCH01, S. marcescens MCH02, S. xylosus MCH03, A. hydrophila $\mathrm{MCH} 04$, and $M$. morganii $\mathrm{MCH} 05$ were reduced by $21-77 \%$ in the presence of the bacteriocin (200 BU/mL) obtained from the tested LAB.

\section{Effect of enzymes, $\mathrm{pH}$, and temperature on antimicrobial activity of the bacteriocin}

These bacteriocins obtained from $P$. acidilactici MCL11 and L. sakei MCL14 remained stable after incubation at $\mathrm{pH}$ 4.0-8.0. However, no the bacteriocin activity was recorded under extremely acidic condition $(\mathrm{pH} 2.0)$. The bacteriocin of $L$. mesenteroides MCL12 and E. faecium MCL13 remained stable after incubation for $24 \mathrm{~h}$ at $\mathrm{pH}$ from 4.0 to 10.0, but not when kept at $\mathrm{pH}$ 2.0. The bacteriocin of $L$. acidophilus MCL15 remained active after $24 \mathrm{~h}$ of exposure to $\mathrm{pH}$ values ranging from 3.0 to 9.0 at $37^{\circ} \mathrm{C}$. The activity of the bacteriocin produced by $P$. acidilactici MCL11, L. mesenteroides MCL12, and E. faecium
MCL13 remained almost completely after heating for $10 \mathrm{~min}$ at $80^{\circ} \mathrm{C}$; however, the bacteriocin activity of these strains was partially destroyed after $10 \mathrm{~min}$ at $100{ }^{\circ} \mathrm{C}$. In particular, the bacteriocin produced by E. faecium MCL13 was inactivated after $10 \mathrm{~min}$ at $120^{\circ} \mathrm{C}$, whereas the inhibitory activity of $L$. sakei MCL14 was $100 \%$ stable to heat treatment at $100{ }^{\circ} \mathrm{C}$ for up to $10 \mathrm{~min}$, and the antimicrobial activity of $L$. acidophilus MCL15 was not affected by the heat treatment for $10 \mathrm{~min}$ at $120{ }^{\circ} \mathrm{C}$. The activity of the bacteriocin produced by $P$. acidilactici MCL11 was destroyed after treatment with papain, pepsin, and proteinase $\mathrm{K}$, but not when treated with $\alpha$-chymotrypsin and trypsin. However, the treatment with papain and proteinase $\mathrm{K}$ had no effect on the activity of the bacteriocin of $L$. mesenteroides MCL12. Treatment of the bacteriocin produced by E. faecium MCL13 with papain and trypsin did not result in any activity loss, but the bacteriocin activity partially inactivated by treatment with pepsin, proteinase $\mathrm{K}$, and $\alpha$-chymotrypsin. Meanwhile, the bacteriocin of $L$. sakei MCL14 was destroyed by all the proteolytic enzymes tested such as papain, pepsin, proteinase $\mathrm{K}$, $\alpha$-chymotrypsin, and trypsin. Complete inactivation in antimicrobial activity of the bacteriocin produced by $L$. acidophilus MC15 was observed after treatment with $\alpha$-chymotrypsin and trypsin. The histamine-degrading ability of the bacteriocin inactivated by some physico-chemical treatments was significantly reduced compared to the control group (Table 4).

The bacteriocin activity of $P$. acidilactici MCL11 was not affected by treatment with $\alpha$-chymotrypsin and trypsin, but was lost after incubation with proteolytic enzymes such as papain, pepsin, and proteinase K. This bacteriocin was stable at up to $80{ }^{\circ} \mathrm{C}$ for $10 \mathrm{~min}$ and was in the $\mathrm{pH}$ range of 4.0-8.0. This is in disagreement with results recorded for pediocin SA-1. Pediocin SA-1 from P. acidilactici NRRLB5627 was inhibitory to several food spoilage bacteria and food-borne pathogens such as Listeria spp. and found to be very effective against the anaerobic Clostridium sporogenes and Clostridium thiaminolyticum (Papagianni and Anastasiadou, 2009). This bacteriocin was heat stable for up to $60 \mathrm{~min}$ at $121{ }^{\circ} \mathrm{C}$, not impaired even following incubation at $30{ }^{\circ} \mathrm{C}$ for 1 week at $\mathrm{pH}$ values ranging between 3.0 and 12.0, and found to be resistant to treatment with trypsin, $\alpha$-chymotrypsin, pepsin, and papain, but not to proteinase $\mathrm{K}$ (Anastasiadou et al., 2008).

The bacteriocin produced by L. mesenteroides MCL12 showed slight resistance to proteolytic enzymes such as $\alpha$-chymotrypsin and trypsin. Treatment of this bacteriocin with papain and proteinase $\mathrm{K}$ had no effect on activity. The activity of this bacteriocin did not decrease after heat treatment at $80{ }^{\circ} \mathrm{C}$ for $10 \mathrm{~min}$ and the stability of the antimicrobial activity was observed at $\mathrm{pH}$ range of 4.0 to 10.0. Characteristics of the bacteriocin produced by $L$. mesenteroides MCL12 were widely different from 


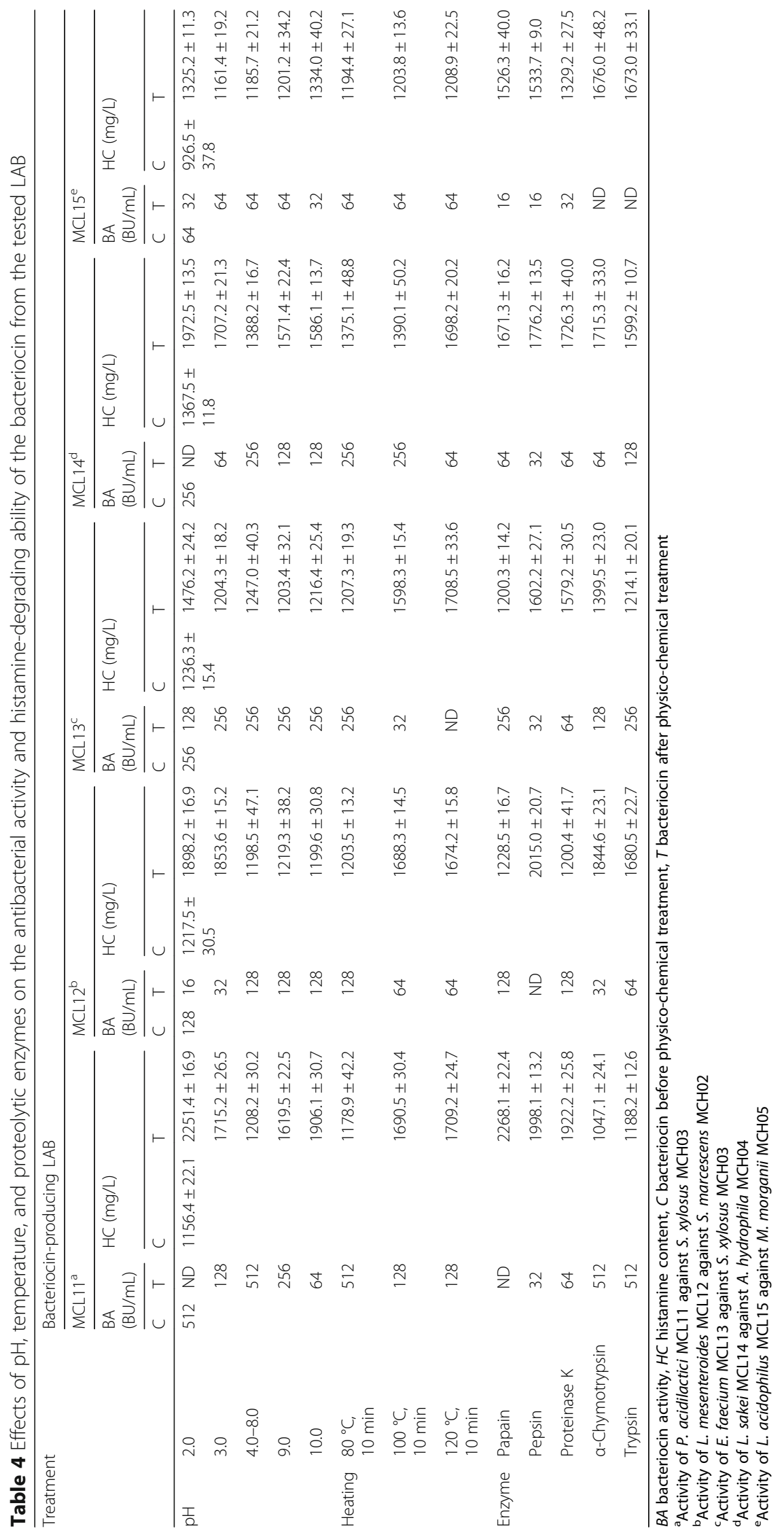


those of the mesentericin Y105. Mesentericin Y105, the bacteriocin from $L$. mesenteroides, had a narrow inhibitory spectrum limited to Listeria genus. Neither the Gram-negative and other Gram-positive indicator bacteria nor the related LAB species were inhibited when tested by the well-diffusion assay. This bacteriocin exhibited excellent stability under heating and acidic conditions. However, all of the proteolytic enzymes such as pronase, proteinase $\mathrm{K}$, trypsin, chymotrypsin, and pepsin totally inhibited the antimicrobial activity of this bacteriocin (Héchard et al., 1992).

The bacteriocin activity of E. faecium MCL13 was stable the $\mathrm{pH}$ range between 3.0 and 10.0. However, a reduction in the activity was observed when the bacteriocin was exposed to $100{ }^{\circ} \mathrm{C}$ for $10 \mathrm{~min}$. The bacteriocin activity was not affected by the presence of papain and trypsin. Unlike our results, the bacteriocins produced by the E. faecium strain showed a broader spectrum of activity against indicator strains of Enterococcus spp., Listeria spp., Clostridium spp., and Propionibacterium spp. This bactercioin was inactivated by $\alpha$-chymotrypsin, proteinase $\mathrm{K}$, trypsin, pronase, pepsin, and papain, but not by lipase, lysozyme, and catalase. The bacteriocin was heat stable and displayed highest activity at neutral $\mathrm{pH}$ (Toit et al., 2000).

Jiang et al. (2012) reported that sakacin LSJ618 produced by the strain $L$. sakei LSJ618 exhibited inhibitory activity against food-spoiling bacteria and food-borne pathogens, including the Gram-positive L. monocytogenes, Staphylococcus aureus, Sarcina spp., Micrococcus luteus, and the Gram-negative Proteus spp. and Escherichia coli, but not against most of the LAB tested. This bacteriocin was completely inactivated by pepsin, papain, trypsin, and lipase, was stable between $\mathrm{pH} 2.0$ and 8.0, and was heat resistant $\left(30 \mathrm{~min}\right.$ at $\left.121{ }^{\circ} \mathrm{C}\right)$, which is partially in agreement with our observations. The bacteriocin of $L$. sakei MCL14 retained their activity at $\mathrm{pH} 4.0-8.0$ and was thermally stable over a wide temperature range up to $100{ }^{\circ} \mathrm{C}$ for $10 \mathrm{~min}$. Also, the bacteriocin activity was unstable after treatment with all the proteolytic enzymes like papain, pepsin, proteinase $\mathrm{K}, \alpha$-chymotrypsin, and trypsin.

The activity of the bacteriocin produced by $L$. acidophilus MCL15 was stable a pH range between 2.0 and 10.0, and remained constant after heating at 80, 100, and $120{ }^{\circ} \mathrm{C}$ for $10 \mathrm{~min}$. However, the bacteriocin activity was destroyed or diminished after treatment with proteolytic enzymes such as papain, pepsin, proteinase $K, \alpha$ chymotrypsin, and trypsin. The same results were recorded for the bacteriocin of $L$. acidophilus IBB 801 . Acidophilin 801 obtained from L. acidophilus IBB 801 strain displayed a narrow inhibitory spectrum, being active particularly towards closely related lactobacilli and two Gram-negative pathogenic bacteria including E. coli Row and Salmonella panama 1467, whereas acidolin and acidophilin produced by L. acidophilus strains showed a wide inhibitory spectrum against Gram-positive and Gram-negative bacteria. The antimicrobial activity of acidophilin 801 was insensitive to catalase but sensitive to proteolytic enzymes such as trypsin, proteinase $\mathrm{K}$, and pronase, heat-stable $\left(30 \mathrm{~min}\right.$ at $\left.121^{\circ} \mathrm{C}\right)$, and maintained in a wide $\mathrm{pH}$ range (pH 3.0-10.0) (Zamfir et al., 1999).

\section{Conclusion}

In conclusion, these bacteriocins produced from the $\mathrm{LAB}$ isolates (P. acidilactici MCL11, L. mesenteroides MCL12, E. faecium MCL13, L. sakei MCL14, and L. acidophilus MCL15) may be a useful as a food biopreservative for controlling microbial deterioration, enhancing the hygienic quality, and extending the shelf-life of fish and seafood products. Notably, these antimicrobial substances may play a role in inhibiting histamine formation in the fermented fish products and preventing seafood-related food-borne disease caused by bacterially-generated histamine.

\section{Abbreviations \\ LAB: lactic acid bacteria; B. licheniformis: Bacillus licheniformis; S. marcescens: Serratia marcescens; S. xylosus: Staphylococcus xylosus; A. hydrophila: Aeromonas hydrophila; M. morganii: Morganella morganii; P. acidilactici: Pediococcus acidilactici; \\ L. mesenteroides: Leuconostoc mesenteroides; E. faecium: Enterococcus faecium; L. sakei: Lactobacillus sakei; L. acidophilus: Lactobacillus acidophilus; GRAS: generally recognized as safe; CFS: cell-free supernatant; BU: bacteriocin unit; K. pneumonia: Klebsiella pneumonia; H. alvei: Hafnia alvei; P. vulgaris: Proteus vulgaris; E. aerogenes: Enterobacter aerogenes; L. buchneri: Lactobacillus buchneri; \\ L. sakei: Lactobacillus sakei; L. lactis: Lactococcus lactis; S. thermophilus: Streptococcus thermophilus; L. monocytogenes: Listeria monocytogenes; E. coli: Escherichia coli}

Acknowledgements

We acknowledge the technical assistance provided by Lee Jong-Gab Professor.

Funding

This Research was supported by the Tongmyong University Research.

Availability of data and materials

Not applicable.

Competing interests

The author declares that he/she has no competing interests.

Consent for publication

Not applicable.

Ethics approval and consent to participate

Not applicable.

Received: 6 September 2016 Accepted: 5 November 2016

Published online: 09 December 2016

\section{References}

An H, Ben-Gigirey B. Scombrotoxin poisoning. In: Millar I, Gray D, Strachan N, editors. Microbiology of seafoods. London: Chapman \& Hall Ltd.; 1998. p. 68-89. Anastasiadou S, Papagianni M, Filiousis G, Ambrosiadis I, Koidis P. Pediocin SA-1, and antimicrobial peptide from Pediococcus acidilactici NRRL B 5627: Production conditions, purification and characterization. Biores Technol. 2008;99:5384-90.

Bover-Cid S, Holzapfel WH. Improved screening procedure for biogenic amine production by lactic acid bacteria. Int J Food Microbiol. 1999;53:33-41.

Brillet A, Pilet MF, Prevost H, Cardinal M, Leroi F. Effect of inoculation of Carnobacterium divergens V41, a bio-preservative strain against Listeria monocytogenes risk, on the microbiological, chemical and sensory quality of cold-smoked salmon. Int J Food Microbiol. 2005;104:309-24. 
Chen HC, Kung HF, Chen WC, Lin WF, Hwang DF, Lee YC, Tsai YH. Determination of histamine and histamine-forming bacteria in tuna dumpling implicated in a food-borne poisoning. Food Chem. 2008;106:612-8.

Cho GS, Do HK. Isolation and identification of lactic acid bacteria isolated from a traditional Jeotgal production in Korea. Ocean Sci J. 2006;41:113-9.

Eerola S, Hinkkanen R, Lindfors E, Hirvi T. Liquid chromatographic determination of biogenic amines in dry sausages. J AOAC Int. 1993;76:575-7.

Gálvez A, Abriouel H, López RL, Omar NB. Bacteriocin-based strategies for food biopreservation. Int J Food Microbiol. 2007;120:51-70.

Garciz-Ruiz A, González-Rompinelli EM, Bartolomé B, Moreno-Arribas V. Potential of wine-associated lactic acid bacteria to degrade biogenic amines. Int J Food Microbiol. 2011;148:115-20.

Gómez-Sala B, Muńoz-Atienza E, Sánchez J, Basanta A, Herranz C, Hernández PE, Cintas LM. Bacteriocin production by lactic acid bacteria isolated from fish, seafood and fish products. Eur Food Res Technol. 2015;241:341-56.

Guan L, Cho KH, Lee JH. Analysis of the cultivable bacterial community in Jeotgal, a Korean salted and fermented seafood, and identification of its dominant bacteria. Food Microbiol. 2011;28:101-13.

Héchard Y, Dérijard B, Letellier F, Cenatiempo Y. Characterization and purification of mesentericin $Y 105$, and anti-Listeria bacteriocin from Leuconostoc mesenteroides. J Gen Microbiol. 1992;138:2725-31.

Hernández-Herrero MM, Roig-Sagués AX, Rodriguez-Jerez JJ, Mora-Ventura MT. Halotolerant and halophilic histamine-forming bacteria isolated during the ripening of salted anchovies (Engraulis encrasicholus). J Food Protect. 1999:5:509-14.

Holo H, Nilssen O, Nes IF. Lactococcin A, a new bacteriocin from Lactococcus lactis subsp. cremoris: isolation and characterization of the protein and its gene. J Bacteriol. 1991;173:3879-87.

Jiang J, Shi B, Zhu D, Cai Q, Chen Y, Li J, Qi K, Zhang M. Characterization of a novel bacteriocin produced by Lactobacillus sakei LSJ618 isolated from traditional Chinese fermented radish. Food Control. 2012;23:338-44.

Joosten HM, Nuńez M. Prevention of histamine formation in cheese by bacteriocinproducing lactic acid bacteria. Appl Environ Microbiol. 1996;62:1178-81.

Kim MK, Mah JH, Hwang HJ. Biogenic amine formation and bacterial contribution in fish, squid and shellfish. Food Chem. 2009;116:87-95.

Kung HF, Wang TY, Huang YR, Lin CS, Wu WS, Lin CM, Tsai YH. Isolation and identification of histamine-forming bacteria in tuna sandwiches. Food Control. 2009:20:1013-7.

López-Sabater El, Rodriguez-Jerez JJ, Hernández-Herrero M, Mora-Ventura MT. Evaluation of histidine decarboxylase activity of bacteria isolated from sardine (Sardina pilchardus) by an enzymatic method. Lett Appl Microbiol. 1994;19:70-5.

Mah JH, Hwang HJ. Effects of food additives on biogenic amine formation in Myeolchi-jeot, a salted and fermented anchovy (Engraulis japonicas). Food Chem. 2003;114:168-73.

Mah JH, Hwang HJ. Inhibition of biogenic amine formation in a salted and fermented anchovy by Staphylococcus xylosus as a protective culture. Food Control. 2009;20:796-801.

Mah JH, Han HK, Oh YJ, Kim MG, Hwang HJ. Biogenic amine in jeotkals, Korean salted and fermented fish products. Food Chem. 2002;79:239-43.

Nugrahani A, Anik H, Hariati M. Characterization of bacteriocin Lactobacillus casei on histamine-forming bacteria. J Life Sci Biomed. 2016;6:15-21.

Papagianni M, Anastasiadou S. Pediocins: the bacteriocins of Pediococci. Sources, production, properties and applications. Microb Cell Fact. 2009;8:1-16.

Rodtong S, Nawong S, Yongsawatdigul J. Histamine accumulation and histamine-forming bacteria in Indian anchovy (Stolephorus indicus). Food Microbiol. 2005;22:475-82.

Santos MHS. Biogenic amines: their importance in foods. Int J Food Microbiol. 1996:29:213-31

Schillinger U, Geisen R, Holzapfel WH. Potential of antagonistic microorganisms and bacteriocins for the biological preservation of foods. Trends Food Sci Technol. 1996;7:158-64.

Shalaby AR. Significance of biogenic amines to food safety and human health. Food Res Int. 1996;29:675-90.

Tabanelli G, Montanari C, Bargossi E, Lanciotti R, Gatto V, Felis G, Torriani S, Gardini F. Control of tyramine and histamine accumulation by lactic acid bacteria using bacteriocin forming lactococci. Int J Food Microbiol. 2014;190:14-23.

Taylor SL. Histamine food poisoning: toxicology and clinical aspects. Crit Rev Toxicol. 1986;17:91-117.
Toit MD, Franz CMAP, Dicks LMT, Holzapfel WH. Preliminary characterization of bacteriocins produced by Enterococcus faecium and Enterococcus faecalis isolated from pig faeces. J Appl Microbiol. 2000;88:482-94.

Visciano P, Schirone M, Tofalo R, Suzzi G. Biogenic amines in raw and processed seafood. Front Microbiol. 2012;3:1-10.

Zacharof MP, Lovitt RW. Bacteriocins produced by lactic acid bacteria. APCBEE Procedia. 2012;2:50-6.

Zaman MZ, Bakar FA, Jinap S, Bakar J. Novel starter cultures to inhibit biogenic amines accumulation during fish sauce fermentation. Int J Food Microbiol. 2011;145:84-91.

Zamfir M, Callewaert R, Cornea PC, Savu L, Vatafu I, De Vuyst L. Purification and characterization of a bacteriocin produced by Lactobacillus acidophilus IBB 801. J Appl Microbiol. 1999:87:923-31.

\section{Submit your next manuscript to BioMed Central and we will help you at every step:}

- We accept pre-submission inquiries

- Our selector tool helps you to find the most relevant journal

- We provide round the clock customer support

- Convenient online submission

- Thorough peer review

- Inclusion in PubMed and all major indexing services

- Maximum visibility for your research

Submit your manuscript at www.biomedcentral.com/submit 